\title{
THE ATTITUDE OF TRUST SHOWED BY KING DAVID IN HOLY BIBLE IN \\ THE BOOK OF PSALM \\ "THE LITERARY WORK THROUGH POETRY FOR CHARACTER EDUCATION"
}

\author{
Maryam Margareta Lughu
}

\begin{abstract}
The purpose of the analysis is to find out the attitude of trust showed by King David in Holy Bible in the book of Psalm. This analysis reveals the attitude of trust that is stated by words in poetry in the book of Psalm. Descriptive Qualitative method is used to analyze primary and secondary data from the book of Psalm and also from the articles or books that support the data by using some steps or procedures that is : to organize and prepare all the data needed, read the data which is the book of Psalm and other references then analyze data by identifying the sentences that represent the statement of having a trust of King David to God. The meaning of this learning both theory and practice is expected to give contribution to the readers about what and how trust is and how they apply it well and correctly.
\end{abstract}

\section{Keywords: attitude of trust, Holy Bible, The Book of Psalm, King David}

\section{Introduction}

The Bible (from Koine Greek $\tau \grave{\alpha} \beta ı \beta \lambda i ́ \alpha$, tà biblia, "the books") is a collection of sacred texts or scriptures that Jews and Christians consider to be a product of divine inspiration and a record of the relationship between God and humans. With estimated total sales of over 5 billion copies, it is widely considered to be the most influential and best-selling book of all time. The Bible has been a massive influence on literature and history, especially in the Western World, where the Gutenberg Bible was the first book printed using movable type. In Masoretic manuscripts (and some printed editions), Psalms, Proverbs and Job are presented in a special two-column form emphasizing the parallel stichs in the verses, which are a function of their poetry. Collectively, these three books are known as Sifrei Emet (an acronym of the titles in Hebrew, , משליוב תהלים, אמ"ת yields Emet, which is also the Hebrew for "truth"). The title is derived from the Greek translation, $\psi \alpha \lambda \mu o$, psalmoi, meaning "instrumental music" and, by extension, "the words accompanying the music". The book is an anthology of individual psalms, with 150 in the Jewish and Western Christian tradition and more in the Eastern Christian churches. Many of the psalms are linked to the name of David.

The name "David" means one who is well beloved. He was born the eighth and youngest son of Jesse, a resident of Bethlehem. He was the great grandson of Ruth (who wrote the book of Ruth) and Boaz (Ruth 4:22). At a young age he tended his father's sheep, a job usually reserved for the LEAST esteemed of the family or its servants. The prophet Samuel makes a special trip to Bethlehem and anoints him the next king of Israel. God chose David to replace Saul who would someday lose his life because he departed from His ways. A few years after his anointing, David fights and takes the life of Goliath the giant, who was a Philistine living in Gath. His basic faith led the future king to conclude that God would ultimately defend those who are his, something the 
entire Israelite army lacked the faith to accept. Their focus was on how experienced and physically powerful was the enemy's champion Goliath. Without faith, it would have been nearly impossible for King David to have defeated such a foe!

Because of a contention over the throne, King David ruled only the tribe of Judah after the death of Saul. His rule over one tribe, which began when he was about 30, lasted seven and one-half years. After this time, all the elders of Israel acknowledge him as the sole ruler over all the tribes. The life of King David ends shortly after proclaiming his son Solomon the next ruler of Israel. He dies at the age of seventy af ter ruling God's people for forty years. The pivotal events and people that occurred while he lived include being anointed leader of Israel as a youth, slaying Goliath the giant, overtaking the Jebusites in Jerusalem and makes the city his capital and bringing the Ark of the Covenant into Jerusalem. He also writes at least 77 of 150 Psalms found in the Bible.

Most individual psalms involve the praise of God-for his power and beneficence, for his creation of the world, and for his past acts of deliverance for Israel. The psalms envision a world in which everyone and everything will praise God, and God in turn will hear their prayers and respond. Worst of all is when God "hides his face" and refuses to respond, because this puts in question the efficacy of prayer which is the underlying assumption of the Book of Psalms. Some psalms are called "maskil" (maschil) because in addition they impart wisdom. Most notable of these is Psalm 142 which is sometimes called the "Maskil of David", others include Psalm 32 and Psalm 78. The term derives from maskil meaning "enlightened" or "wise". In the book of Psalm, it is also stated about how much King David put his trust on God to protect him from evils through his words to God. (www.wikipedia.com)

In this analysis, the writer would love to reveal how much trust he has to God and how he sees all the miracles and blessings. To get miracle or blessing from God is not that easy too because at the moment we ask something from God, that moment God wants us to trust Him to make it happen based on His own way. The problem is the most people usually lose their trust when in the middle of the time in pursuing the will then hit by some problems and sometimes it is so easy to build that trust again. It is easy to say that we trust something but for reality is hard to imply the word of trust through our attitude.

A trust is a fiduciary arrangement that allows a third party, or trustee, to hold assets on behalf of a beneficiary or beneficiaries. Trusts can be arranged in many ways and can specify exactly how and when the assets pass to the beneficiaries. Assets in a trust may also be able to pass outside of probate, saving time, court fees, and potentially reducing estate taxes as well.

Other benefits of trusts include:

- Control of your wealth.

You can specify the terms of a trust precisely, controlling when and to whom distributions may be made. You may also, for example, set up a revocable trust so that the trust assets remain accessible to you during your lifetime while designating to whom the remaining assets will pass thereafter, even when there are complex situations such as children from more than one marriage.

- Protection of your legacy. 
A properly constructed trust can help protect your estate from your heirs' creditors or from beneficiaries who may not be adept at money management.

- Privacy and probate savings.

Probate is a matter of public record; a trust may allow assets to pass outside of probate and remain private, in addition to possibly reducing the amount lost to court fees and taxes in the process. (https://www.fidelity.com/life-events/estateplanning/trusts)

According to Luke Arthur on his updated article on July 27, 2017, he defines trust as one of the most common tools in estate planning is a trust. A trust is a tool that allows an individual to decide in advance what should happen to his assets af ter he is gone. Trusts can also be used to minimize taxes and protect assets from creditors. (https://pocketsense.com/trusts-8052432.html) while another definition states that trust is reliance on the integrity, strength, ability, surety, etc., of a person or thing; confidence or confident expectation of something; hope or confidence in the certainty of future payment for property or goods received; credit (https://www.dictionary.com/browse/trust)

Trust is divided into four main categories, which are based on when it goes into effect and who owns the assets. All Trusts are set up by you, the grantor, during your life. However, not all Trusts immediately go into effect. Depending on when it becomes effective, it's either a Living Trust or a Testamentary Trust.

1. Living Trusts:

When a Trust is created and then immediately become effective.

2. Testamentary Trusts:

When a Trust is created and then does not become effective until after your death. These are often created within Wills, and the person who created it is called the "testator."

3. Revocable Trusts:

You retain ownership and control of the property in the trust and can change the terms, including the trustees and beneficiaries.

4. Irrevocable Trusts:

You give ownership and control of the property in the Trust to others (Trustees) and no longer own or control the property, thus making you unable to enact changes.

\section{Methodology \\ Design}

This analysis is about how to reveal the trust showed by King David to God in Holy Bible in the book of Psalm. The analysis uses Qualitative Research which is in descriptive form because the data collected are in the form of words or pictures rather than number. The written result of the research contains quotations from data to illustrate and substantiate the presentation (1982:30). Method of Qualitative Research is a research procedure that produce descriptive data in the form of words written or spoken word from the people. It is called qualitative because of the nature of the data collected qualitative and patterned using a measurement tool (2004:3). Based on the statement given, the words, statement, quotations, and other references deal with the analysis should be collected to make this done well. 
Data resources

In doing this analysis, both primary and secondary sources are collected. The Holy Bible of King James Version of the book of Psalm (150 chapters) is the primary source while the secondary source is taken from the articles or books related to this topic.

Data Analysis

In analyzing the data, there are some steps have been used. They are:

1. Organize and prepare all the data needed.

2. Read all the data which is the book of Psalm and other references taken.

3. Analyze the data in which the sentences that representatives the statement of trust

\section{Finding and Discussion}

What is trust?

The definition of trusts

Trust has been defined in different ways by the researchers and often reflects the paradigms of the researchers' academic discipline. The most frequently cited definition is: "Trust is the willingness of a party to be vulnerable to the action of another party based on the expectation that the other will perform a particular action important to the trustor, irrespective to the ability to monitor orcontrol that other party". This definition implies that there is something important to be lost by the trustor (i.e., vulnerability). Trust is a very effective complexity reduction method, although the user cannot have control on the behaviour of others. This implies the lack of control.

Corritore et al. define online trust as "an attitude of confident expectation in an online situation of risk that one's vulnerabilities will not be exploited". The authors include some key concepts in their definition, which are risk, vulnerability, expectation, confidence, and exploitation. Chang et al. define trust as "the belief that the Trusting Agent has in the Trusted Agent's willingness and capability to deliver a quality of service in a given context and in a given Timeslot". This definition implies the contextspecific characteristic of trust. "Trust is about the ability to predict the behaviour of another party". Grandison and Sloman define trust as "the firm belief in the competence of an entity to act dependably, securely, and reliably within the specified context". The authors defined distrust as "the lack of firm belief in the competence of an entity to act dependably, securely and reliably within a specified context". The authors mentioned that trust is a composition of multiple attributes such as reliability, honesty, dependability, security, timeliness, and competence, and different attributes have to be considered in different environments where trust will be established. There are two common definitions of trust in literature: reliability trust and decision trust. Reliability trust is a context where A relies and expects B to perform a given action on which its welfare depends. This definition includes the dependency and the reliability concepts. Decision trust is "the extent to which one party is willing to depend on something or 
somebody in a given situation with a feel ing of relative security, even though negative consequences are possible". This trust definition includes the concepts of dependency, reliability, utility, risk attitude, law enforcement,insurance and other remedies. In Web Services, trust is defined in the WS-Trust specification as "the characteristic that one entity is willing to rely upon a second entity to execute a set of actions and/or to make assertions about a set of subjects and/or scopes". This definition misses the concepts of vulnerability, risk, lack of control, and context-specificity. Other studies define and specify trust or reputation as one of the QoS .Dragoni mentioned that evaluation of trust is a key QoS aspect of Web Service selection. Maximilian and Singh present the selection of a Web Service based on non-functional attributes such as QoS and trust. Kalepu et al. add a "verity" metric to the QoS properties for Web Service selection and define it as "the ability to maintain the lowest difference between the projected and achieved levels of service metrics". However, trust is not a QoS. QoS properties can be used as information to establish trust. Often, trust is confused and used sy nony mously with terms such as cooperation, faith, competence, reliance and credibility. Cooperation is either a cause or a manifestation of trust. Trust includes reason but faith is the opposite of reason. Trust goes beyond the belief in the competence of the trusted party. Trust in information means that the information is credible or believable]. It is possible to rely on a person without trusting him/her. Mayer et al. add the confidence and predictability terms as synonymous terms. With trust, risk is assumed, but with confidence it is not.

Trust Principles

Defining trust principles is important to establish trust. We proposes the following trust principles based on the exploration and analysis of trust literature in the offline and the online worlds and the extension of online trust principles. The developer of a trust system is required to consider the following principles that form a basis to establish trust.

A. Trust and risk

Risk is "the likelihood of an undesirable outcome" . Risk is an intrinsic part of everyday life. There is an agreement that trust only exists in a risky and uncertain environment. Mayer et al. State that "the need of trust arises in a risky situation". Therefore, the trustor should have something to lose if trust is violated. If the trustor has a higher perception of control, the less he has a need to trust. Less perception of control increases the risk. Trust is the expectation of the trustee's behaviour in risky circumstances and the extent of their commitment to the rules. There has been very little work on the analysis of the relationship between risk and trust. Risk is the core of trust. Therefore, a technique is required to ensure an entity's reliability in risky exchange situations. In addition, it is important also to include penalties, rewards, insurance, and other risk remedies in case something goes wrong to support trust intention.

B. Trust development phases

Trust goes through three development phases: trust building, stabilising trust, and dissolution. Although most studies assume a system where trust and reputations already exist (i.e.,stabilising trust phase), it is important to initialise a trust rate for a new entity (i.e., building trust phase) and to address trust failure and 
reconstruction (i.e., dissolution trust phase). To establish trust, the process should consider all three trust development phases. In the trust building phase, initial trust formation is important. For example, the system should initially assign trust rate for any new comer that has no rate. This phase is a crucial stage in any trust relationship. In the stabilizing trust phase, trust evolves over time and is based on interaction and observation between parties. In this phase, trust is based, for example, on the trustor's knowledge on the trustee from past interactions or recommendation from other parties. In the dissolution trust phase, trust could be declined, and it is important to study the situations of trust decline and trust rebuilding after a decline.

C. Dynamic nature of trust

Trust is dynamic. Trust changes over time and with further experiences. Maximilien and Singh identifies self- adjusting trust that is an important characteristic in an open environment. Self-adjusting trust is "The autonomic characteristic of a multi-agent system whereby the levels of trust between the interacting parties are dynamically established and adjusted to reflect recent interactions". Trust establishment should consider the dynamic nature of trust. This requires continuous evaluation of entities' trustworthiness. Trust broker opinion, reputation, recommendation, and referral, are some approaches used, for example, to evaluate, test, personalise, evolve, and ensure trust.

D. Trust and identity

Trust depends on identity. Having identity enables the history (i.e., past experience) of the interactions to be built and mapped to that identity. Identities allow ratings about a specific party from the past to be associated with that same party in the future. While in the real word the identity can be established by visual recognition or identification, in the online world, the identity is established using authentication and tokens. Trust can be formed by join values, tasks, and goals, and by creating collective identity (e.g., common team name). The identity trust class ensures that entity's identity is as claimed. Authentication is a mechanism where both parties prove that they are acting with each other. Some of authentication methods are: user name and password, digital certificate, or tokens. Those methods are used to define the identity of the trustee. Authentication systems provide such identity using authentication techniques (such as X.509 and PGP).

E. Categories of Trust Semantics

Semantics characteristic of trust scores is important to interpret their measurements' meaning. Trust can be measured based on a specific measure of one trust aspect (e.g., performance) or on general measure, which represents the average of all aspects (e.g., performance, accuracy, and availability). Trust measurement can be based on judgement or calculation to assess the trustworthiness of an entity. Those measurement approaches provide many alternatives to evaluate trust in trust-based systems. In addition, using those approaches can provide a flexible way for the trustor to select trustees based on trustor preferences. 
F. Trust relationship properties

Trust is usually specified in terms of a relationship between a trustor and a trustee. Trust relation can be one-to-one between a trustor and a trustee, one-to-many between a trustor and a group of entities, many-to-one such as between the members and the manager of a department, and many-to-many such as the mutual trust between members of a group.

Trust may not be symmetric or transitive. A trust relationship is not absolute in that the trustor trusts a trustee with respect to its ability to perform a specific action within a specific context. Context specificity implies the multifaceted and different degrees aspects of trust. Trust varies with the individual, organisation, and situation. This requires a requestor to specify the degree level of different trust aspects for different entities. For example, executing code in the systems needs higher level of trust than just writing to a file, and writing to a file needs a higher level of trust than only reading a file (resource access trust).

G. Global and local rate

There are two trust rates to predict the trustworthiness of the trustee: local and global rates. Global trust rate is a unique trust score independent of the user who did the evaluation and define how the community as a whole trusts a specific trustee (i.e., unique reputation seen by all users). Local trust rate depend s on the user doing the evaluation (i.e., personalized score). Therefore, each trustee may have different local rates seen by different users. Global trust requires TTP to collect reputations (feedbacks) from the trustors about trustees in different situations. Local trust requires the user to build personalised rate about trustees and TTPs. The advantage of the global rate is that it communicates the experiences, but the information is potentially unreliable and comes from unknown or anonymous second parties. Local trust is more reliable and based on user preferences. Therefore, considering both global and local rates is important to establish trust, which helps the trustor to make a better selection decision.

H. Trust is based on information

There is a need to know information about the other party to establish trust. A challenge question is: What information should be used to build trust? Information has many dimensions and each entity set its own information dimensions and builds an information model. Entities in online world traverse many domains with different properties and requirements. For example, a requestor of a service has many requirements and each seeks for different services' properties. Therefore, defining a unified trust information for such an open environment is a challenge. Some studies try to define a notion of community or address trust in specific domain to overcome this problem.

I. First party information

A first party (a trustee) should provide their information to develop trust. For example, information such as performance, security, and privacy is used by many commercial sites to help establish trust. QoS properties and other information (e.g., delivery methods, insurance, privacy, security, pricing, availability) can be considered as important information on which to build trust. Other information can help, such as the providers' properties.

J. Third party ratings 
An expert opinion from a TTP such as certification authority, service broker, or a trust broker, plays an importantrole in trust establishment, evolution, and self adjustment. TTP helps the users to get rates of different entities even without having direct experience with that entity. A TTP can aggregate feedbacks and trust rates from trustors, calculate the rates, and provide them globally. In addition, TTP can assess thetrustworthiness of an entity by doing self calculation and evaluation of the entities and provide its opinion globally. Trustors con sult a TTP for the trustworthiness of a trustee. The assumption is that this TTP is a trusted party and the consumers rely on its result. Assuming that TTP is a trusted party constitutes the introduction of a security hole and it is important to plug this hole.

K. Trust approaches

Trust approaches, as discussed in Section I, such as direct experience, reputation, recommendation, referral and matchmaking help build and evolve trust. Those approaches help provide global/local rates. Combining different trust approaches (i.e Hybrid approach) improves some of the other approaches' weaknesses and results in a better and more robust approach to establish trust. Weaknesses and challenges in trust literature (e.g., unfair rating) should be resolved in trust establishment process.

L. The distinction between trust and QoS

There is a clear distinction between trust and QoS definitions. Trust is not a QoS aspect of an entity. In Web Services, trust has been studied as a QoS or based on a set of QoS properties. However, trust goes beyond QoS of a Web Service. QoS properties can be used as trust information to establish trust. A clear distinction between the two terms should be considered in the trust establishment process.

M. Security and privacy

Security and privacy are important factors to consider in the trust establishment process. Security and privacy are considered as important trust information to establish trust in online-banking and e-marketing. For security, the uncertainty of transactions can bring several risks because of the technology infrastructure or the actors involved in the online transaction. A technique is required to ensure security and this help establish trust. For privacy, a trustee should accomplishes a task and do not disclose the trustor's information. A technique is requiredto protect the privacy of a trustor's and this help to build trust.

N. Provider's trustworthiness

Trust ratings of a service and its provider are related and each one affects the other. A trustworthy service provider provides trustworthy services. The trustor of a service can select a service based on the service's rate or/and the service provider's rate. For example, a trustor trusts Amazon site for services it provides. Trust in Internet has a clear distinction between the trust-worthiness of the services and the providers. The studies have identified quality requirements for providers to assist their trustworthiness and help the user on his/her decision to usethe providers' services. In web services, the idea of trusting a web service based on its provider is neglected. However, there are little studies, which cover trusting providers. Considering a provider rates will encourage the provider to 
provide high quality services because the trust rate of the provider and each of its services are related.

O. Trustor preferences

Trust is context specific, muti-faceted, not absolute, matter of degree, and may not be symmetric or transitive. Therefore, a trust-based system should support trustor preferences. The importance of trustor preferences comes from the difference on preferences between different trustors. This will imply different trust rates for the same trustee seen by different trustors (i.e., personalized trust rate). A trustor should be able to select a trustee based on the trustor preferences. In service selection, a requestor may request a service based on its performance and security, given a degree of $60 \%$ forthe performance and $100 \%$ for the security. The web is anopen system that spans different countries, regulations, and cultures. Those differences impact the trust building process. Consider trustor preferences mitigates the division of trust between different countries and cultures.

P. Trust classes

Provision, delegation, context, and certification of trustee are trust classes. To establish trust, it is important to consider trust classes. In provision trust, a requestor can rely on a trust broker to rate a trustee and seek protection rom malicious services. Delegation plays a big role in trust establishment. A trustor can delegate a TTP or an agent to act on his/her behalf to identify an entity's trustworthiness. In context trust, the system can support trust by having the ability to support transactions and do remedies (e.g., use law enforcement, insurance) in case something goes wrong. Certification of the trustee can help to build trust. Having a certification from third parties can enhance and ensure the trustee's trustworthiness. A trustor should trust certification from the TTP given to the trustee.

\section{The History of Trusts}

The concept of the trust has been around longer than most people realize. As the story goes, the very first trust dates back to the days of the Roman Empire - about 800 A.D. In that society, only citizens of Rome could own property. When faced with deployment, soldiers would transfer ownership of their property to a trusted friend to make sure their families were cared for. During the Roman occupation of the British Isles, the trust became a familiar tool to protect lands from rogue governors and lords. The concept of the trust arrived on American soil along with the colonists.

\section{The Structure of a Trust}

Every trust must have four primary elements. The first element is the tru st maker - the person who makes the trust. This person can also be called the "Grantor" or "Settlor." The second element is the person who manages the trust assets and performs the functions of the trust. This person is called the "Trustee" and can sometimes be the same person as the trust maker or can be a professional or institutional trustee. There are more levels of trusteeship. For instance, when the original trustees are deceased or no longer to serve, then another person is appointed to take their place. That person is called the "Successor Trustee." The third element is the person or class of persons who will benefit from the existence and operation of the trust. This person is called a 
"Beneficiary" and the original beneficiary is sometimes the trust maker, however in many types of trusts the trust maker is not the beneficiary. After the trust maker is deceased, then normally their children become the next line of beneficiaries. Of course, if more than one person exists, they are called "Beneficiaries." The final element consists of the assets inside the trust. These assets are called the trust Corpus." (Randall W. McKee, RFC : 1)

\section{The book of Psalm}

The book of psalm consists of 150 chapters. The meaning and theology of the book of Psalm is really debated till this time. It tends to put all Psalm in Sitz im Leben (the history situation) bigger than the life of old Israel beliefs (like William F. Albright and David Noel Freedman). The Diachronic approach uses romantic literary works to build the frame of thought of development of Israel worship. Gerstenberger differs some steps from individual to family or tribe/region to national religious identity by putting the temple of God as the center. According to Limburg and Waltke, the book of Psalm is divided into some parts :

1. Introduction : (Psalm 1-2) the half considers this as a singular psalm which full of happiness words from psalm 1 and 2. Psalm 1 tells about to invite the right men to meditate the words of God while Psalm 2 talks about annointed King in Sion Mountain.

2. Scripture 1 : (Psalm $3-41$ )

Revealing about David and asking God protection from the enemies

3. Scripture 2: (Psalm $42-72$ )

Psalm 42 - 49 come from Corah tribe with a family who take a responsibility of the music in the temple of God while 51-65 and 68-70 are Psalm of David.

4. Scripture 3: (Psalm 73-89)

Psalm 73 - 83 come from Asaf and others explain about the lamentationof covenant sin and sadness situation of the nation.

5. Scripture 4 : (Psalm $90-106)$

It states that there is a new hope when Jesus as a king and does His will to the world. Moses is in the center (it is mentioned 7 times), shows that God has saved Israel can do the same thing. Eventhough the kingdom does not exist any more but God can save the people.

6. Scripture 5 : (Psalm $107-145)$

It is synthesized that God has helped Israel when they have problem (Psalm 108 $-110,138-145)$. Psalm $120-143$ are religious songs about the journey to Jerusalem to worship God

7. Conclusion : (Psalm $146-150)$

Jews tradition is really sure that collection as a reflection for 5 scripture of Pentateuch. It is considered as thematic history about Israel with the summary of each is : Scripture 1 is about the conflict between David and Saul, Scripture 2 explains about David as the King, Asyur crisis is revealed in Scripture 3, Scripture 4 describes the total destruction of God's temple and exile and Sripture 5 tells about worship with meditation after returning from exile (Hill and Watson, 2000:346). Usually Psalm indicates about worship songs with its figurative language inside and the prophecies of God is usually made in form of 
poetry because it is easy to be remembered and more emotional and stronger to state the message. The melody is variatif in Psalm. It has 8 parts :

1. The battle songs

2. Songs of Solomon

3. The lamentation

4. The solemn songs (worship)

5. The solemn songs of gratitude to God

6. The songs of celebration or confirmation

7. Psalm of wisdom and teaching

8. Psalm of curses

The theme is the most about worship and prayer. Psalm shows the awareness of Israel to God better than the other scriptures. It is seen as the center of all fields in the world and it is theology and it is clearly stated that God is on the throne. Besides that, it has an holistic exegesis related to the nature of poetry and figurative langu a ge such as hyperbole in psalm of curses. It also reveals about the wisdom of life in front of God and every aspect in any ways should be related to the way of Israel worship and ritual.

Trust showed by King David in the Book of Psalm

From the data, it is found that there are some chapters or parts that support the statement of having a trust to God showed by King david in the book of Psalm is in the part of

1.1 Introduction : Psalm $1-2$

Psalm 1 tells about to invite the right men to meditate the words of God while Psalm 2 talks about annointed King in Sion Mountain.

1.2 Scripture 1 : Psalm 3 - 41

Revealing about David and asking God protection from the enemies. In this part, David put his own trust tat God the only one as his shield for every thing. He puts the biggest trust that nobody even evil can destroy him if he has God with him.

1.3 Scripture 4 : psalm $90-106$

It states that there is a new hope when Jesus as a king and does His will to the world. Moses is in the center (it is mentioned 7 times), shows that God has saved Israel can do the same thing. Eventhough the kingdom does not exist any more but God can save the people. Eventhough people nowadays can not talk face to face like commom people do when they want to tell or communicate something but the strongest holy spirit always save God's people who do trust on Him.

1.4 Scripture 5 : Psalm $107-145$

It is synthesized that God has helped Israel when they have problem (Psalm 108 $-110,138-145)$. Psalm $120-143$ are religious songs about the journey to Jerusalem to worship God.

All the chapters above reveal about the attitude of trust in God showed by King david because he feels so comfort, safe and happy to be with God and he feels God's protection from the enemies and he really believes that God has saved Israel and He will always does the same thing to His chosen nation. Having the attitude of trust should be had by two parties or some because if one rejects that thing, the relationship will not run well. It is shown clearly that both God and David has the same trust so at the moment 
when David is chosen to lead the people of Israel, he put his trust personally in God to manage all things happen and God also trust david to lead His chosen nation, Israel.

\section{Conclusion and Suggestion}

Conclusion

Trust is a complex subjective term. Based on the analysis of trust, the trust definition should includes the concepts of dependency, confidence expectation, vulnerability, reliability, comfort, utility, context-specificity, risk attitude, and lack of control. In addition, the definition should show the assessment of trust by calculating promised utility. Trust should not be used synonymously with many terms such as trustworthiness, cooperation, faith, or QoS. Therefore, this work proposes the following definition of trust: Trust is the willingness of the trustor to rely on a trustee to do what is promised in a given context, irrespective of theability to monitor or control the trus tee, and even though negative consequences may occur. A trustworthy entity is an entity that behaves according to its promised role, that reciprocates a trustor's trust by completingthe interaction as agreed, and holds a positive attitude toward the trustor's goodwill and welfare. For example, a trustworthy entity has a high reliability, perf orms an action within reasonable time, and will not disclose privacy information.

By analyzing this part, it reveals that in the book of Psalm, there are some that state the attitude of trust showed by King david. As it is explained before, the parts that support or representative the trust are in Introduction, Scripture 1, Scripture 4 and Scripture 5. As it is known that David is a chosen man to lead the kingdom of Israel as a chosen nation of God. He is annointed by the prophet Samuel with the blessing given by God that is why David has a very strong attitude of trusting God in handling everything eventhough he is not a perfect man. It is a very great thing to do because having the attitude of trusting and being trusted can make life be great in doing and facing all things.

\section{Suggestion}

It is suggested for those to learn more about the literary work through poetry in book of Psalm. From the analysis, we can know more about what the exegesis of Psalm, the figurative languages and the other detail things. It is also great to be learnt because we can know the history, the wisdom, the worship and prayer especially to those Christian s the .ore we know to whom we should put the trust

\section{REFERENCES}

Abdul-Rahman. A, 1997. “The PGP trust model,” Journal of Electronic Commerce. Bodgan, R and Bikklen, S. 1982.Qualitative Research for Education: An Introduction to Theory and Methods, Second Edition. Boston : Alliyn and Bacon, Inc

Blois K. J. 1999. "Trust in business to business relationships: An evaluation of its status," Journal of Management Studies, vol. 36, no. 2, pp. 197-215, 03.

Buttyan L and Hubaux. J. 2007. Security and Cooperation in Wireless Networks: Thwarting Malicious and Selfish Behavior in the Age of Ubiquitous Computing. New York, NY, USA: Cambridge University Press. 
Chang. E, T. Dillon, and H ussain. F. 2005. "Trust and reputation relationships in service-oriented environments," ICITA 2005. Third International Conference on Information Technology and Applications, vol. 1, pp. 4-14 vol.1, july.

Corritore C. L, Kracher B, and Wiedenbeck. S. 2003. "On-line trust: concepts, evolving themes, a model," Int. J. Hum.-Comput. Stud., vol. 58, no. 6, pp. 737-758.

Dragoni. N. 2009. "Toward trustworthy web services - approaches, weaknesses and trust-by-contract framework," IEEE/WIC/ACM International Conference on Web Intelligence and Intelligent Agent Technology, vol. 3, pp. 599-606.

Dyke. J. V. 2004. "Establishing federated trust networks among web services," Bachelor thesis of Science in Computer Engineering, University of Virginia.

Entrust. April 2001. "Web services trust and xml security standards,".

Gambetta D . 1988 "Can we trust trust?" in Trust: Making and Breaking Co operative Relations. Basil Blackwell, , pp. 213-237.

Grandison T and Sloman S. 2000. "A survey of trust in internet applications." IEEE Communications Surveys and Tutorials, vol. 3, no. 4.

Hill, Andrew E and Walton, John H. 2000. A Survey of Old Testament, Ed. 2. Grand rapids: Zondervan

https://www.fidelity.com/life-events/estate-planning/trusts

https://pocketsense.com/trusts-8052432.html - Arthur Luke. July,27. 2017

https://www.dictionary.com/browse/trust

Huhns M. Singh Nand M. P. 2005. "Service-oriented computing: Key concepts and principles," IEEE Internet Computing, vol. 9, pp. 75-81.

Jøsang. A, Ismail R, and Boyd C 2007. "A survey of trust and reputation systems for online service provision,” Decis. Support Syst., vol. 43, no. 2, pp. 618-644.

Kalepu. S, Krishnaswamy S, and Loke S. Dec. 2003. "Verity: a QoS metric for selecting web services and providers," Proceedings Fourth WISEW, pp. $131-139$.

Kautonen T and Karjaluoto, Eds. 2008. Trust and New Technologies: Marketing and Management on the Internet and Mobile Media. Edward Elgar.

Kelvin. L, Chris K, Anthony N, Marc G, Martin G, Abbie B, and Hans G. February 2009. "Ws-trust 1.4," Tech. Rep.

Limburg James. 1992. "Psalms, Book of." Didalam ABD Ed. David Noel Freedman, 5 : 522-36. New York : Doubleday.

Malik. Z and Bouguettaya A. 2009. "Reputation bootstrapping for trust establishment among web services," IEEE Internet Computing, vol. 13, no. 1, pp. 40-47.

Martin M. Shenkman www.laweasy.com

Massa. P and Avesani P. 2007. "Trust metrics on controversial users: balancing between tyranny of the majority and echo chambers," International Journal on Semantic web and Information Systems.

Maximilien. E and Singh M. 2004. "Toward autonomic web services trust and selection," in ICSOC, M. Aiello, M. Aoyama, F. Curbera, and M. P. Papazoglou, Eds. ACM, pp. 212-221.

Mayer R. C, Davis J. H, and Schoorman F. D. 1995. "An integrative model of organizational trust," The Academy of Management Review, vol. 20, no. 3, pp. 709734.

McKnight. D. H and Chervany N. L. 1996. "The meanings of trust," Technical report MISRC Working Paper, University of Minnesota. 
Mr. Henry Abts III and his firm The Estate Plan http://theestateplan.com

Osborne, Grant T. 2006. "The Hermeneutical Spiral : A Comprehensive Introduction to Biblical Interpretation- Second Edition, revised and expanded”. USA-Illinois : Downers Group - InterVarsity Press.

Papazoglou. M. 2008. Web Services: Principles and Technology. Printice Hall.

Parera, Djos, Daniel. 2004. Teori Semantik. Jakarta : Erlangga.

Stephen Leimberg - The New, New Book of Trusts Alexander Bove - The Complete Book of Wills, Estates and Trusts

Song. R, Korba L, and Yee G. 2007. Trust in E-services: Technologies,Practices and Challenges. IGI Global.

The Holy Bible King James Version. 2011. USA - New York : Hendrickson Publisher. The National Network of Estate Planning Attorneys http://the.nnepa.com/public/Default.asp? $\mathrm{m}=\mathrm{p}$

The American Academy of Estate Planning Attorneys www.aaepa.com/topten.aspx The National Institute of Certified Estate Planners www.nicep.org

The American Academy of Certified Estate Planners www.americanestateplanners.com Wang Yand J. Vassileva. 2007. "A review on trust and reputation for web service selection," in ICDCSW '07: Proceedings of the 27th International Conference on Distributed Computing Systems Workshops. Washington, DC, USA: IEEE Computer Society, p. 25.

Wellek, rene and Warren Austin. 1956. "Theory of Literature”. New York : Hartcourt, Brace and World.

www.wikipedia.com

Ying-feng Z and Pei-ji S. oct. 2006. "The model for consumer trust in c2c online auction," ICMSE '06 International Conference on Management Science and Engineering, pp. $125-129$.

Zacharia. G, Moukas A, and Maes P. 2000. "Collaborative reputation me ch anis ms for electronic marketplaces," Decision Support Systems, vol. 29, no. 4, pp. 371-388. 